\title{
PEMAHAMAN DAN REALITAS IMPLEMENTASI WORKPLACE SPIRITUALITY DALAM PERENCANAAN DAN PELAKSANAAN ANGGARAN
}

\author{
Iismiati $^{1}$ \\ A.A.N.B. Dwirandra ${ }^{2}$ \\ ${ }^{1,2}$ Fakultas Ekonomi dan Bisnis Universitas Udayana, Bali, Indonesia \\ ${ }^{1}$ Email: ismicaem81@yahoo.co.id
}

\begin{abstract}
ABSTRAK
Penelitian ini dilatarbelakangi oleh konsep manusia seutuhnya yang belum terimplementasi sepenuhnya di tempat kerja, karena kebanyakan orang menganggap tempat kerja adalah tempat untuk mencari sesuatu yang bersifat duniawi dengan melupakan kehidupan batin dan mengabaikan nilai-nilai agama. Tujuan penelitian adalah untuk memahami realitas workplace spirituality dalam perencanaan dan pelaksanaan anggaran. Data penelitian diperoleh melalui wawancara mendalam dan observasi partisipatif, yang kemudian dianalisis dengan Analisis Fenomenologi Interpretatif (AFI). Hasil penelitian menginterpretasikan pemahaman informan tentang workplace spirituality menjadi 3 (tiga) sudut pandang yaitu pandangan intrinsik, pandangan agama, dan pandangan eksistensialis. Realitas workplace spirituality dalam perencanaan dan pelaksanaan anggaran belum sepenuhnya sesuai dengan pemahaman informan karena adanya penyimpangan, dikarenakan perilaku aparatur masih mengabaikan nilai-nilai spiritualitas. Ketidakselarasan antara realitas dengan pemahaman workplace spirituality dalam perencanaan dan pelaksanaan anggaran diperlukan faktor pengendali seperti suprastruktur pimpinan, lingkungan kerja, dan personal value.
\end{abstract}

Kata kunci: perilaku, perencanaan anggaran, pelaksanaan anggaran, workplace spirituality

\begin{abstract}
This research is motivated by a whole human concept that has not been fully implemented in the workplace, as most people consider the workplace is a place to seek something worldly by forgetting the inner life and ignoring religious values. The purpose of this research is to understand the reality of workplace spirituality in planning and implementation of budget. Research data obtained through in-depth interviews and participatory observation then it is analyzed by Interpretative Phenomenological Analysis. The results of the study interpret the understanding of informant's about workplace spirituality understanding into 3 (three) perspectives namely intrinsic views, religious views, and existentialist views. The reality of workplace spirituality in planning and implementation of budget has not been fully compatible with its understanding because of deviations and the behavior of the apparatus still ignores the spiritual values. The dissonance between reality of workplace spirituality in planning and implementation of budget with understanding of workplace spirituality is required the controlling factors such as leadership superstructure, work environment, and personal value.
\end{abstract}

Keywords : behaviour, budget planning, budget implementation, workplace spirituality 


\section{PENDAHULUAN}

Penganggaran sektor publik merupakan suatu proses yang rumit dan berbeda dengan organisasi non publik, karena harus diinformasikan, dievaluasi, dikritik oleh publik untuk mendapatkan masukan, dimana penganggaran ini sangat syarat dengan nuasa politiknya (Mardiasmo, 2009:61). Penganggaran sektor publik, dalam perencanaan dan penganggaran sangat melibatkan perilaku aparatur dalam menentukan kebijakan dan keberhasilan tujuan pemerintahan. Perilaku aparatur sangat berpengaruh dalam penyusunan anggaran, karena aparaturlah yang menyusun anggaran dan juga harus hidup dengan anggaran (Tuasikal, 2015).

Berdasarkan teori keagenan, aparatur pemerintah sebagai agen yang diberikan kewenangan oleh pimpinan instansi (prinsipal) untuk menyusun, mengelola serta melaporkan anggaran dapat menggunakan kesempatan tersebut untuk melakukan asimetri informasi. Keleluasaan agen dengan adanya asimetri informasi tersebut dapat mendasari perilaku opportunistik aparatur dalam perencanaan dan pelaksanaan anggaran. Salah satu contoh perilaku opportunistik dalam penganggaran adalah melakukan slack anggaran dan melaporkan keuangan yang tidak sesuai dengan belanja riilnya. Slack anggaran yang terjadi dalam penganggaran seperti menggunakan anggaran untuk membiayai kegiatan yang mengandung unsur kepentingan tertentu, dan memaksimalkan nilai anggaran melebihi estimasi sesungguhnya untuk mendapatkan penilaian kinerja yang baik dikemudian hari. Perilaku aparatur yang seperti ini dapat menimbulkan korupsi.

Garanfalvi (1997 dalam Abdullah dan Asmara, 2006) menyatakan bahwa korupsi dapat terjadi pada setiap tahapan penganggaran mulai dari perencanaan 
sampai pada pembayaran dana-dana publik. Kasus korupsi pada tahap perencanaan disebut political corruption, karena nuansa politik lebih dominan dalam pengambilan keputusannya. Sedangkan pada tahap pelaksanaan, kasus korupsi yang terjadi adalah administration corruption, karena faktor administrasi lebih dominan (Abdullah dan Asmara, 2006), seperti penyiasatan laporan "SPJ" yang $100 \%$ padahal belanja belum tentu $100 \%$ (Setiawan, dkk, 2013) yang mengakibatkan adanya kebocoran dalam belanja APBN yang tidak diketahui (Juono, 2009).

Salah satu penyebab terjadinya korupsi adalah perilaku negatif government official menjadi rasionalisasi tindakan fraud (Stalebrink dan Sacco, 2007) dan kebanyakan aparatur menganggap tempat kerja adalah tempat untuk mencari halhal profan (duniawi) dan tidak memiliki ruang untuk sesuatu yang suci (Amalia dan Yunizar, 2007) serta mengabaikan nilai-nilai agama dan norma masyarakat (Rahman, 2012 dalam Mansyur 2013). Akibatnya, terjadi pemisahan antara kebutuhan dunia dan akhirat di tempat kerja, sehingga seseorang bekerja hanya berfokus pada karir dan rutinitas tanpa memperhatikan kehidupan batin (Rachman dkk, 2014). Padahal, kodrat manusia sebagai makhluk dua-dimensional (Mulia, 2012) tidak hanya memerlukan kebutuhan dunia, tetapi mendambakan kebutuhan akhirat (batin) seperti kedamaian, ketenteraman, dan keimanan kepada Tuhan (Dwirandra, 2011). Berdasarkan keinginan untuk menyeimbangkan kebutuhan dunia dan akhirat di tempat kerja, muncullah kajian baru pada bidang psikologi organisasi yang berfokus pada nilai-nilai spiritualitas dalam pekerjaan yang disebut workplace spirituality (spiritualitas di tempat kerja). 
Workplace spirituality merupakan konsep pemahaman individu sebagai makhluk spiritual yang membutuhkan pemeliharaan di tempat kerja, memberikan makna dalam bekerja, serta memiliki perasaan terhubung dengan orang lain di tempat kerja, sehingga kebahagiaan dan kesejahteraan dapat tercapai dalam kehidupan manusia dengan menyeimbangkan kebutuhan material dan kebutuhan spiritual (Ashmon dan Duchon, 2000). Konsep ini mulai diteliti pada tahun 1990an di Amerika yang dapat meningkatkan kinerja karyawan (James, et all, 2011), meningkatkan produktivitas, pemecahan masalah, efisiensi organisasi (Weitz et all, 2012), kepuasan kerja, etos kerja yang tinggi dan komitmen kepada organisasi (Mulyono, 2011; Hapsari dkk, 2015; Haryokusumo, 2015). Workplace spirituality juga dapat membantu karyawan dalam mengontrol perilaku mereka di tempat kerja serta menghasilkan perilaku organisasi yang kewarganegaraan (Ahmad \& Omar, 2015). Windarto (2016) menyatakan bahwa workplace spirituality dapat dikaitkan dengan pelaksanaan anggaran, karena pelaksanaan anggaran memerlukan nilai kejujuran, tanggung jawab, integritas, dapat dipercaya dan perilaku etis dalam pengambilan keputusannya sehingga praktek kecurangan yang rawan dalam pelaksanaan anggaran dapat diminimalisir dengan perilaku aparatur yang berjiwa spiritual.

Penelitian terkait workplace spirituality yang dihubungkan dengan perilaku individu di tempat kerja telah diteliti oleh Gupta and Sing (2016), Pawar (2009), Ahmad and Omar (2016), Amalia dan Yunizar (2007), Yogatama dan Widyarini (2015), dan Sufya (2016) yang menyatakan bahwa workplace spirituality dapat mempengaruhi perilaku karyawan untuk bekerja lebih kreatif, inovatif, jujur, 
kepercayaan dan menempatkan bekerja sebagai ibadah. Namun Kumari (2012) berpendapat lain bahwa workplace spirituality kemungkinan dapat mengakibatkan pelanggaran karena adanya tekanan (agresi). Prinsip yang terkandung dalam dimensi workplace spirituality seperti kehidupan batin, tujuan dan makna bekerja, dan keterhubungan dengan komunitas di tempat kerja diharapkan dapat menjadikan tempat kerja sebagai organisasi spiritual yaitu generasi yang membawa nilai-nilai spiritual tidak hanya pada lingkungan organisasi tetapi mengamalkannya dalam setiap aktivitas yang dilaksanakan (Pradiansyah, 2007).

Ikhtisar Hasil Pemeriksaan Semester (IHPS) I Tahun 2016, mencatat kasus korupsi di Indonesia sebanyak 210 kasus dengan kerugian sekitar Rp 890,5 Milyar. Fakta korupsi ini, dialami juga oleh Kementerian Agama (Kemenag) sebagai satu-satunya kementerian yang mengurusi tentang agama, dimana pejabat dan pegawainya sering memberikan pencerahan keagamaan kepada masyarakat. Korupsi di Kemenag mulai tercatat sejak tahun 2010 sampai 2016, baik dalam bidang perencanaan maupun pelaksanaan anggaran bahkan melibatkan menteri agama Suryadarma Ali sebagai tersangka. Penerapan multi DIPA dalam penganggaran dapat melahirkan perilaku opportunistik aparatur dalam menyusun anggaran, karena pengelola diberikan kewenangan untuk menyusun dan melaksanakan sendiri anggarannya. Selain itu Setiawan (2015) mengatakan bahwa di Kemenag masih menjalankan praktik-praktik ketidakjujuran berupa "penyiasatan" yang menjadi budaya atau kebiasaan yang diterima secara biasa.

Untuk mendapatkan gambaran tentang pemahaman dan realitas workplace spirituality dalam perencanaan dan pelaksanaan anggaran, maka peneliti 
melakukan penelitian pada salah satu Satuan Kerja (Satker) Kantor Wilayah (Kanwil) Kemenag di Pulau Sunda Kecil dengan beberapa alasan; Pertama institusi ini masih mengalami penyimpangan administratif berdasarkan hasil audit kinerja oleh Inspektorat Kemenag; Kedua, institusi ini oleh Menpan pada Tahun 2014 ditetapkan sebagai Wilayah Bebas Korupsi (WBK); dan Ketiga, institusi ini telah berusaha menghadirkan nilai-nilai spiritualitas di tempat kerja seperti keharusan sholat berjamaah pada dzuhur dan ashar, doa bersama setiap hari pukul 12 siang, pengajian rutin, pembinaan mental pegawai pada hari besar keagamaan, dan perjalanan religius ke tempat suci. Pemaparan fenomena di atas, membuat peneliti tertarik untuk meneliti lebih dalam terkait pemahaman dan realitas implementasi workplace spirituality dalam perencanaan dan pelaksanaan anggaran dengan pendekatan kualitatif.

Berdasarkan latar belakang yang telah disampaikan, maka rumusan masalah penelitian ini antara lain, (1) bagaimana pemahaman informan tentang workplace spirituality; (2) bagaimana implementasi dan realitas workplace spirituality dalam perencanaan dan pelaksanaan anggaran; dan (3) bagaimana model pemahaman dan realitas workplace spirituality dalam perencanaan dan pelaksanaan anggaran persepsi aparatur.

\section{METODE PENELITIAN}

Penelitian ini mengenai pemahaman aparatur tentang implementasi dan realitas workplace spirituality dalam perencanaan dan pelaksanaan anggaran. Pendekatan yang digunakan dalam penelitian ini adalah pendekatan fenomenologi yang bersifat kualitatif dengan paradigma interpretif sebagai payung penelitian. 
Tujuan pendekatan fenomenologi untuk menyelidiki pengalaman berdasarkan kesadaran individu yang ada dibalik fenomena (Kuswarno, 2009:2). Alasan digunakannya pendekatan ini adalah para fenomenolog yakin bahwa kesadaran terbentuk bukan karena kebetulan, tetapi dibentuk dari pengalaman dan kehidupan sehari-hari (Moleong, 2014:16).

Penelitian ini dilaksanakan selama 2 bulan (Juli - Agustus 2017) pada salah satu Satker Kanwil Kemenag di pulau sunda kecil. Informan penelitian merupakan aparatur yang terlibat langsung dalam perencanaan dan pelaksanaan anggaran dari beberapa bidang yang ada dan mewakili ideologi agama sebanyak 6 (enam) orang. Identitas informan merupakan nama samaran untuk menggantikan nama aslinya. Pemilihan informan ditentukan berdasarkan key person (Bungin, 2009) atas pertimbangan pribadi peneliti dan melibatkan pihak luar yaitu rekan kerja dan pembimbing.

Data dikumpulkan dengan observasi partisipatif dan wawancara mendalam. Observasi partisipatif dilakukan dengan cara pengamatan langsung di setting penelitian atas segala situasi dan tindakan masing-masing individu (Dwirandra, 2011). Wawancara mendalam dilaksanakan secara tidak terstruktur tergantung jawaban informan dalam situasi yang santai dan menyenangkan.

Analisis data penelitian dilakukan dengan Analisis Fenomenologi Interpretatif (AFI) yang terdiri dari 6 (enam) tahap yaitu reading and re-reading, initial noting, developing emergent themes, searching for connection across emergent themes, moving the next cases, dan looking for patterns across cases (Smith, et al, 2009: 79-107). Tahap pertama, peneliti membaca berulang-ulang 
hasil manuskrip untuk menemukan fakta menarik dari setiap informan. Tahap kedua, menganalisis isi/kontens dari kata-kata yang diucapkan informan berdasarkan interpretasi peneliti, Tahap ketiga, mengidentifikasi kemunculan tema dari masing-masing informan dan kemudian diurutkan secara kronologis. Tahap selanjutnya, merangkum hasil analisis masing- masing manuskrip menjadi satu rumusan tema yang ditampilkan melalui master table untuk memudahkan menarik simpulan. Sebelum hasil penelitian dilaporkan, peneliti melakukan verifikasi data untuk mendapatkan informasi yang sesuai dengan realitas di lapangan.

Proses penggalian kemunculan tema-tema dalam penelitian berdasarkan pemahaman informan tentang permasalahan penelitian menghasilkan 3 (tiga) tema pokok penelitian yaitu: (1) pemahaman workplace spirituality perspektif informan; (2) implementasi dan realitas workplace spirituality dalam perencanaan dan pelaksanaan anggaran; dan (3) model pemahaman dan realitas workplace spirituality dalam perencanaan dan pelaksanaan anggaran. Ketiga tema pokok penelitian disajikan dalam bentuk narasi, kutipan-kutipan dan gambar yang kemudian dihubungkan dengan hasil penelitian terdahulu.

Untuk melihat keabsahan dari hasil penelitian, peneliti melakukan member cheking yaitu kembali ke setting penelitian untuk memvalidasi informasi (Creswell, 2007; Chariri, 2009). Validasi dilakukan untuk menghindari kesalapahaman interpretasi antara peneliti dengan informan. Setelah mendapat persetujuan dari informan, baru hasil penelitian dilaporkan secara lengkap yang melukiskan pemahaman dan realitas workplace spirituality dalam perencanaan dan pelaksanaan anggaran. 


\section{HASIL DAN PEMBAHASAN}

\section{Pemahaman Workplace Spirituality Perspektif Informan}

Konsep workplace spirituality belum dapat didefinisikan dengan jelas, karena masih ada tujuh puluh definisi workplace spirituality yang tidak diterima secara umum (Gupta \& Singh, 2015). Penelitian ini pun menghasilkan pendapatan informan yang berbeda-beda terkait pemahaman beliau tentang workplace spirituality. Pandangan masing-masing informan terkait pemahaman workplace spirituality ditampilkan pada Tabel 1 di bawah ini.

Tabel 1

Pemahaman Workplace Spirituality Perspektif Informan

\begin{tabular}{|c|c|c|c|}
\hline No & Informan & Hasil Wawancara & Makna Spiritual \\
\hline 1 & Danang & $\begin{array}{l}\text { Spirit memunculkan tujuan, tujuan } \\
\text { menimbulkan spirit yang menyemangati } \\
\text { melalui kerjasama antar rekan kerja, } \\
\text { organisasi, atasan dan lingkungan kerja. } \\
\text { (M.D2-02,03) }\end{array}$ & $\begin{array}{ll}\text { - } & \text { Menemukan tujuan } \\
\text { - } & \text { Spirit menyemangati } \\
\text { - } & \text { Kerjasama/sinergi }\end{array}$ \\
\hline 2 & Riana & $\begin{array}{l}\text { Ucapan syukur kepada Tuhan yang } \\
\text { memotivasi kita untuk memaksimalkan } \\
\text { apa yang kita punya, bekerja dengan baik, } \\
\text { dan melaksanakan segala pekerjaan } \\
\text { dengan baik. (M.R1-03,04) }\end{array}$ & $\begin{array}{l}\text { - Ucapan syukur } \\
\text { - Bekerja dengan baik }\end{array}$ \\
\hline 3 & Junaidi & $\begin{array}{l}\text { Melihat kerja sebagai ibadah, ada } \\
\text { maknanya. Orientasi kerja untuk mencari } \\
\text { makna bukan hasil yang masuk ke } \\
\text { kantong, sehingga kerja itu enak dan } \\
\text { hidup ada artinya. (M.J1-04) }\end{array}$ & - Bekerja sebagai ibadah \\
\hline 4 & Halimah & $\begin{array}{l}\text { Penerapan nilai-nilai ajaran agama ketika } \\
\text { melakukan pekerjaan di tempat kerja, } \\
\text { mengedepankan sifat baik dalam bekerja, } \\
\text { kejujuran, bekerja dengan benar dan } \\
\text { bekerja dengan amanah. (M.H1-03,04) }\end{array}$ & $\begin{array}{l}\text { - Penerapan nilai agama } \\
\text { - Bekerja dengan baik } \\
\text { - Kejujuran } \\
\text { - Amanah }\end{array}$ \\
\hline 5 & Yongki & $\begin{array}{l}\text { Menjauhkan diri dari hal-hal yang tidak } \\
\text { baik dalam bekerja, menjaga untuk tetap } \\
\text { berada di jalur yang benar sesuai dengan } \\
\text { ajaran agama. (M.Y1-02) }\end{array}$ & $\begin{array}{l}\text { - Bekerja sesuai ajaran } \\
\text { agama }\end{array}$ \\
\hline 6 & Sastro & $\begin{array}{l}\text { Motivasi, semangat, ketekunan dalam } \\
\text { menyelesaian pekerjaan dengan jalan } \\
\text { yang benar untuk mencapai hasil, dan } \\
\text { sesuai dengan aturan yang berlaku. } \\
\text { (M.S1-03) }\end{array}$ & $\begin{array}{l}\text { - } \text { Motivasi } \\
\text { - } \text { Semangat } \\
\text { - } \text { Ketekunan } \\
\text { - } \text { Sesuai aturan yang } \\
\text { berlaku }\end{array}$ \\
\hline
\end{tabular}

Sumber: Dikembangkan peneliti, 2017 
Berdasarkan hasil wawancara yang dipaparkan dalam Tabel 1, maka disimpulkan bahwa informan memahami workplace spirituality dari berbagai sudut pandang yang berbeda sesuai dengan pengalaman dan pengetahuannya tentang spiritualitas. Adapun pemahaman informan terkait workplace spirituality ini dibagi menjadi 3 (tiga) sudut pandang yang dikemukan oleh Krishnakumar and Neck (2002) yaitu pandangan intrinsik, agama dan eksistensialis.

Pandangan intrinsik diungkapkan oleh Danang, Riana dan Sastro, dimana pandangan ini berasal dari dalam diri individu yang mungkin berbeda antar individu karena tidak ada aturan yang mengikatnya (Sulistyo; 2011) serta melewati batas nilai keyakinan termasuk aturan agama (Guillory's; 2000). Pandangan ini memberikan pemahaman bahwa workplace spirituality merupakan nilai-nilai universal yang lahir dari dalam diri individu seperti ucapan syukur kepada Tuhan, menemukan tujuan hidup dalam bekerja, memiliki semangat bekerja, meningkatkan sinergisitas untuk mencapai tujuan, bekerja dengan baik, bekerja dengan mengedepankan kejujuran, bekerja dengan amanah, motivasi, ketekunan mencapai hasil dan bekerja sesuai dengan aturan yang berlaku. Temuan ini sesuai dengan Prihono, dkk ((2016); Javanmard (2012) dan Rahmat, dkk (2014) menyatakan bahwa workplace spirituality merupakan sebuah semangat untuk menemukan tujuan, bekerja lebih baik dan menyenangkan, bekerja sesuai dengan aturan, bertanggungjawab, menyelesaikan pekerjaan dengan baik, memotivasi, dan bekerja dengan jujur. Penelitian ini menemukan temuan baru dimana workplace spirituality adalah suatu bentuk ucapan syukur kepada Tuhan dan ketekunan dalam bekerja untuk mencapai hasil yang maksimal. 
Pemahaman workplace spirituality berdasarkan pandangan agama yang diungkapkan oleh Halimah dan Yongki, menyatakan bahwa workplace spirituality adalah penerapan nilai-nilai ajaran agama seperti kejujuran, kebenaran dan kebaikan serta selalu berada di jalur yang benar sesuai dengan ajaran agama. Pandangan ini sesuai dengan Webster yang mendefinisikan bahwa spiritualitas berhubungan dengan aturan-aturan gereja atau segala sesuatu yang berhubungan dengan nilai agama (Zamor, 2003). Rahmat, dkk (2014) dan Windarto (2016) menyatakan bahwa workplace spirituality merupakan lingkungan kerja yang aktivitas kerjanya selalu berdasarkan pada pelaksanaan nilai-nilai yang terkandung dalam ajaran agama dan kepercayaan.

Sedangkan pandangan eksistensialis berdasarkan pendapat Krishnakumar dan Neck (2002) menyatakan bahwa spiritualitas merupakan konsep pencarian makna dalam diri setiap individu terhadap sesuatu yang dikerjakannya. Pemahaman Junaidi tentang workplace spirituality sebagai suatu bentuk ibadah dapat dikatakan sebagai pandangan eksistensialis, karena eksistensialis memandang kehidupan manusia harus sesuai dengan fitrahnya sebagai makhluk Tuhan, sehingga bekerja untuk mencari makna dari kehidupan itu sendiri. Bekerja sebagai ibadah merupakan pencarian makna dalam bekerja sehingga akan membawa hidup lebih berarti.

\section{Implementasi dan Realitas Workplace Spirituality dalam Perencanaan Anggaran}

Perencanaan anggaran merupakan tahap awal yang akan menentukan keberhasilan suatu instansi mencapai tujuan berdasarkan anggaran yang akan dikelolanya. Berdasarkan pemahaman masing-masing informan ditemukan bahwa 
semangat workplace spirituality telah menjiwai setiap pribadi informan yang diimplementasikan dalam aktivitas sehari-harinya dalam bekerja di bidang perencanaan anggaran, tetapi realitasnya workplace spirituality dalam perencanaan anggaran belum sepenuhnya diaplikasikan karena masih adanya niatan penyimpangan yang akhirnya dilaksanakan pada saat pelaksanaan anggaran.

Semangat workplace spirituality yang telah diimplementasikan dalam perencanaan anggaran adalah sikap pasrah dan mengalah dalam perencanaan; mengawali bekerja dengan menyebut nama Tuhan, berdoa dan sesaji; bekerja sesuai dengan aturan dan bermanfaat kepada umat; serta mengedapankan sikap kekeluargaan, saling membantu dan kepedulian terhadap rekan kerja. Sikap pasrah dan mengalah dalam perencanaan disampaikan informan sebagai bentuk tanggunjawab mereka terhadap pekerjaan, sehingga apapun hasil yang mereka dapat setelah berusaha adalah sesuatu yang harus disyukuri. Mensyukuri hasil dapat diwujudkan dalam bentuk bekerja secara amanah dan penuh rasa tanggung jawab, seperti yang diungkapkan oleh Danang dan Riana berikut ini:

"Selama ini, kalau sudah seperti itu, kita cuma bisa berpikir kembali tuk tahun berikutnya, tahun ini mungkin sudah tidak bisa ditambah ya kan secara penganggaran gak mungkin lagi, kita berpikir dan berjuang untuk tahun berikutnya." (M.D1-10)

"Iya diterima.... coba dipertahankan dulu dengan alasan justifikasi yang masuk akal, kalau sudah diterima ya syukur, kalau gak ya sudah..." (M.R1-06)

Ungkapan kedua informan ini memberi makna bahwa bekerja secara amanah dalam perencanaan anggaran berarti melaksanakan pekerjaan dengan lebih baik sesuai batas maksimal yang dimilikinya dan merupakan salah satu sifat 
Nabi Muhammad SAW dan salah satu sifat Allah yaitu Al Wakill (Maha Pemanggul Amanah). Bekerja dengan amanah juga akan menjauhkan diri dari halhal yang berbau kebohongan atau merekayasa anggaran. Aparatur perencana yang amanah akan bekerja selalu mengingat Tuhan dan menganggap bahwa apa yang dia kerjakan merupakan tanggung jawab kepada Tuhan. Windarto (2016) menyatakan bahwa pertanggungjawaban anggaran tidak hanya secara fisik antar manusia (bawahan dan atasan), tetapi juga antara manusia dengan Tuhan.

Selain mengedepankan sikap pasrah dan mengalah, informan juga selalu mengawali pekerjaan dengan menyebut nama Tuhan, berdoa, sesaji sebagai ungkapan rasa syukur kepada Tuhan yang telah memberikan kita kehidupan dan pekerjaan. Informan yakin bahwa memulai pekerjaan dengan menyebut nama Tuhan, berdoa dan sesaji dapat memberikan semangat dalam bekerja, sehingga pekerjaan akan dilakukan dengan sepenuh hati, seperti yang diungkapkan oleh Yongki dan Halimah berikut:

“...berdoa itu supaya kita ingat melakukan hal yang baik yang diajarkan, bekerja...pasti bekerja itu hal yang baik kan. Pokoknya supaya di tempat kerja itu kita baik itu aja. Kalau kita sudah mengawali hari dengan bersyukur, kita bisa berpikir bahwa kemarin kita sudah melalui hari dengan baik, kenapa gak saya lalui hari ini dengan baik seperti kemarin lagi, dengan melihat masa lalu kita bisa memperbaiki masa depan, itu mungkin...” (M.Y1-19,20)

"Trus berdoa aja sich mbak, berdoa....dan ketika memulai pekerjaan baca bismillah gitu aja lah....dan kemudian ikutin aturan yang sudah diberlakukan...." (M.H1-20)

Dalam konteks perencanaan anggaran, jika selalu mengingat Tuhan dalam setiap aktivitasnya akan membawa kenyaman dalam bekerja dan kejujuran. Agustian (2007:129) menyatakan bahwa mengawali suatu pekerjaan dengan menyebut nama Tuhan seperti membaca "bismillah" berarti kita sudah mengawali 
pekerjaan dengan menetapkan hati untuk melakukan pekerjaan dengan kemuliaan namaNya, menebarkan rasa kasih sayang, dan tidak merugikan orang lain.

Makna dan tujuan bekerja dalam perencanaan anggaran adalah bekerja sesuai dengan aturan dan bermanfaat kepada umat merupakan tujuan yang mulia dalam perencanaan anggaran. Informan menyatakan bahwa perencanaan telah dilakukan sesuai dengan aturan yang ada yaitu sesuai dengan Peraturan Menteri Keuangan (PMK) Nomor 143 Tahun 2015 dan standar biaya, serta berdasarkan RKP dan ADIK yang ditetapkan oleh Eselon 1, seperti ungkapan Danang berikut:

“...Kita dahulukan RKP, biasanya orang perencanaan sudah paham karena sudah ada ADIK yang mengatur. Karena itulah kita mendahulukan RKP, jika ada sisa baru kita sisir untuk kegiatan lain" (M.D1-09)

Selain sesuai dengan aturan, tujuan perencanaan anggaran bagi informan adalah memberikan manfaat kepada umat, sehingga perencanaan anggaran selalu diusulkan berdasarkan kebutuhan umat, seperti yang diungkapkan oleh Yongki berikut:

"Menurut saya sih....memang bermanfaat untuk masyarakat, merencanakannya memang berdasarkan apa yang dibutuhkan oleh masyarakat..." (M.Y1-26)

Ungkapan kedua informan ini memberikan makna bahwa bekerja sesuai aturan dan bermanfaat bagi umat dapat menjadi kekuatan di tempat kerja untuk menjalankan budaya integritas, kejujuran, loyalitas, keamanan kerja, kepedulian, tanggung jawab, keterbukaan serta perjuangan untuk pencapaian tujuan organisasi. Budaya integritas merupakan salah satu budaya organisasi di institusi Kemenag selain profesional, inovasi, tanggung jawab dan keteladanan. Windarto (2016) menjelaskan bahwa integritas dapat diwujudkan melalui konsistensi 
pelaksanaan peraturan yang berlaku. Bekerja agar bermanfaat kepada umat berarti memberikan kontribusi kepada masyarakat sebagai suatu wujud kepedulian sosial. Ashmon dan Duchon (2000) dan Rahmat, dkk (2014) menyatakan bahwa workplace spirituality dapat meningkatkan semangat kepedulian dan kontribusi kepada masyarakat secara lebih berarti (Smith dan Rayment, 2007).

Mengedepankan sikap kekeluargaan, saling membantu dan kepedulian terhadap rekan kerja juga terimplementasi dalam perencanaan anggaran, sebagaimana ungkapan Sastro yang menyatakan bahwa anggaran yang diperoleh hanya perlu disyukuri dan dipertanyakan jika itu menyangkut pelayanan kepada masyarakat, karena pelayanan masyarakat adalah bentuk pengabdiannya kepada instansi. Selain itu, Halimah dan Junaidi juga menjelaskan bahwa anggaran yang di dapat harus dikomunikasikan kepada seluruh seksi melalui rapat dan dibagi berdasarkan kebutuhan sesuai data secara transparan. Hal ini dilakukan untuk menciptakan perasaan nyaman dalam bekerja, kekeluargaan, saling membantu, dan rasa kepedulian antar sesama rekan kerja dalam perencanaan anggaran. Ashmon dan Duchon (2000) menyatakan bahwa workplace spirituality berkaitan dengan kepedulian individu terhadap kondisi sosial anggota dalam organisaasi yang tercermin dari sikap tolong menolong, bekerjasama, saling menghargai dan rasa kekeluargaan.

Implementasi workplace spirituality yang telah informan pahami sangat tidak realistis dengan kenyataan bahwa dalam perencanaan anggaran masih menyimpan motif/niat tersembunyi untuk memenuhi kepentingan tertentu. Niatan ini disampaikan oleh dua informan, dimana perencanaan anggaran selalu berusaha 
memaksimalkan anggaran untuk mendapatkan sesuatu yang lebih untuk kesejahteraan pegawai dan kebersamaan, seperti ungkapan berikut:

“Alasannya pagunya ada, dan kita mengapresiasi pekerjaan kita, apa yang kita kerjakan. Dan supaya akhir tahun ada plus-plusnya (sudah tau kan ya...), terpenting untuk R1, R2 (sudah tau kan ya...)" (M.R1-17)

“... Kayak gitu kan, mau gak mau kan kita kayak sungkan punya kegiatan kok teman-teman gak diajak ramai-ramai padahal bantuin, kita maksimalin dah, bukan maksimalin tapi konsumsi kita beli berapa tapi dapatnya berapa. Misalnya uangnya 400 juta, eh... 40 juta tapi buat semua teman sama peserta, jadi ada dah....nyeplitin konsumsi buat teman-teman.” (M.H1-17).

Pernyataan ini membuktikan bahwa dalam proses perencanaan anggaran sudah berusaha untuk mencari celah aturan mana yang bisa digunakan untuk mendapatkan kepentingan tertentu.

Garanfalvi (1997) berpendapat bahwa korupsi dapat terjadi pada setiap level penganggaran yaitu sejak perencanaan sampai pada pembayaran dana-dana publik (Abdulah dan Asmara, 2006). Setiawan (2013) juga menyatakan bahwa setiap bidang di SKPD telah memahami titik-titik mana yang dapat "disiasati" agar kepentingan pribadi juga kepentingan kantor dapat berjalan dengan baik berkat dukungan dana yang memadai. Implementasi dan realitas workplace spirituality menurut informan mengungkapkan kondisi aparatur yang harus melakukan pelanggaran demi kepentingan tertentu. Niatan pelanggaran ini dilakukan karena adanya desakan dari atasan dan tradisi sungkan sebagai orang timur yang sudah menjadi kebiasan untuk menjamu orang lain dengan baik. Sprung, dkk (2012) dan Kumari (2013) juga menyatakan bahwa spiritualitas di tempat kerja kemungkinan akan terjadi pelanggaran bila terdapat tekanan (agresi) di tempat kerja. 


\section{Implementasi dan Realitas Workplace Spirituality dalam Pelaksanaan Anggaran}

Pelaksanaan anggaran adalah dokumen yang membuat pendapatan, belanja, dan pembiayaan yang digunakan sebagai dasar pelaksanaan anggaran oleh Pengguna Anggaran (PA) (Permendagri, 2006:8). Pelaksanaan anggaran merupakan tahapan kegiatan yang sangat penting dalam rangka penyelenggaraan kegiatan, karena dengan dilaksanakannya pelaksanaan anggaran berarti program dan rencana operasional tahunan dapat segera dilaksanakan. Anggaran yang sudah dilaksanakan harus dipertanggungjawabkan dalam bentuk laporan pertanggungjawaban kegiatan (dibaca "SPJ"). Laporan SPJ kegiatan harus sesuai dengan aturan yang ada, karena akan diperiksa baik oleh Irjen maupun BPK.

Implementasi workplace spirituality dalam pelaksanaan anggaran sudah berusaha diwujudkan oleh informan melalui sikap pasrah, tanggung jawab dan saling membantu dalam menjalankan pelaksanaan anggaran yang sesuai dengan aturan yang ada. Namun dibalik implementasi workplace spirituality yang sesuai dengan aturan yang mereka jalankan terdapat realitas bentuk penyimpangan. Bentuk penyimpangan ini berupa pelaporan belanja kegiatan yang tidak sesuai dengan belanja riilnya, karena harus memperoleh dana tambahan untuk operasional kantor yang sering disebut dana taktis, sebagaimana ungkapan informan berikut:

"Kayaknya sich ada sich.....kayaknya ada sich menurut saya...... karena gini......(berhenti sejenak) dana taktis, pasti ada menurut saya pasti ada, kalau gak kayak gitu gimana" (M.J1-38)

"Memang salah sebenarnya.......berartikan melebihkan satuan yang kita beli kan, cuma terkadang sudah kebiasaan kayaknya anggaran segini tapi belinya segini..." (M.H1-32) 
Dana taktis yang dimaksud adalah selisih antara total belanja yang dipertanggungjawabkan (“di-SPJ-kan”) secara administratif dengan belanja riilnya (Setiawan dkk, 2013). Perolehan dana taktis ini sangat berbeda dengan dana Sisa Lebih Perhitungan Anggaran (SiLPA), karena SiLPA diperoleh dari selisih lebih realisasi penerimaan dan pengeluaran anggaran selama satu periode anggaran yang bersifat formal sedangkan dana taktis diperoleh dari selisih belanja yang dipertanggungjawabkan dan bersifat informal. Temuan ini sesuai dengan Windarto (2016) yang menyatakan bahwa pertanggungjawaban pelaksanaan anggaran masih dalam sisi administrasi dan kurangnya pengamalan nilai-nilai agama. Selain itu Sprung, dkk (2012) dan Kumari (2013) juga menyatakan bahwa spiritualitas di tempat kerja kemungkinan akan terjadi penyimpangan bila terdapat tekanan (agresi) di tempat kerja.

Berdasarkan penggalian informasi yang lebih dalam kepada empat informan, terdapat tiga faktor yang menjadi penyebab mengapa informan melakukan penyiasatan dalam pelaporan kegiatan yang tidak sesuai dengan riilnya yaitu atasan, kebiasaan turun temurun, dan ketakutan aparatur akan dimutasi. Atasan/pimpinan sebagai pemegang kewenangan atas pelaksanaan anggaran sebagai Pejabat Pembuat Komitmen (PPK) memiliki otoritas untuk memerintah bawahannya melakukan sesuatu yang akan menjadi tanggung jawabnya. Hal ini diungkapkan oleh informan penelitian sebagai berikut:

"Iya.....gimana lagi, sudah gak bisa lagi.... kita sebagai pelaksana kita hanya manut kepada yang ngasi keputusan, yang sebenarnya itu salah..” (M.Y1-34)

“...Kebijakan atasan kali ya.... Kalau atasan bilang gak usah ada potongan di belanja bahan, yakin dech pasti gak ada. Seandainya kita yang bilang gak 
usah ada potongan di belanja bahan, terus pak Kabid bilang "potong" gak mungkin kita bilang uang sendiri aja pak...” (M.H1-49)

Ungkapan kedua informan ini mengindikasikan bahwa peran otoritas atasan sangat besar dalam pelaksanaan anggaran yang menjadi tanggungjawabnya, sehingga informan sebagai staf hanya bisa pasrah melaksanakan perintah atasan yang diketahuinya adalah salah. Hasil temuan ini sesuai dengan Murphy \& Mayhew (2012); Sofyani dan Pramita (2014); Bawa dan Yasa (2016) yang menyatakan bahwa pimpinan memiliki otoritas legal rasional dalam sistem birokrasi (Weber, 2009) dan dapat digunakan dalam mempengaruhi bawahan untuk melakukan perilaku tidak etis. Penyiasatan laporan merupakan bentuk kecurangan pelaporan keuangan dan merupakan perilaku yang tidak etis. Selain itu, atasan yang memberikan otoritas kepada stafnya untuk melakukan kecurangan laporan realisasi anggaran akan menjadikan otoritas tersebut sebagai motif rasionalisasi pelanggaran dan mempersepsikann tanggung jawab kecurangan akan ditanggung oleh atasannya (Sofyani dan Pramita, 2014).

Kebiasaan turun temurun yang merupakan suatu kebiasaan yang salah dalam organisasi dan kebutuhan akan dana tambahan untuk operasional kantor yang tidak ada di DIPA menjadi alasan selanjutnya informan melakukan penyiasatan laporan SPJ. Informan menganggap bahwa kebiasaan ini sudah diketahui oleh semua anggota instansi serta dilakukan secara berjamaah menjadi sebuah kebersamaan dalam instansi. Kebiasaan yang telah lama berlangsung ini sulit untuk diubah apalagi dihapuskan yang dikatakan informan sebagai "rahasia umum”. Berikut beberapa ungkapan informan: 
"Iya itu tadi.....konsep pemikirannya masih orde baru, dimana dari dulu pembiarannya dibiarkan terus kan, sudah terbiasa jadinya, jadi budaya lamalama, dan itu hal yang salah di anggap jadi benar aja... terlalu dibiarkan.." (M.Y1-38)

"Hahaha.....mau gimana ya, karena sudah rahasia umum, yang disana bilang sah, disana bilang sah, iya sah, sah...." (M.R1-32)

"Iya gimana ya....hehehe...sudah rahasia umum sih mbak sebenarnya... Pastilah itu ada cuma kita kan tanya ini untuk apa sih sebenarnya, nyisainnya untuk apa...." (M.H1-29)

Bentuk kebiasaan yang dilakukan informan ini menyiratkan bahwa pelaporan kegiatan yang tidak sesuai dengan riilnya menjadi sesuatu yang telah biasa dilakukan instansi untuk mendapatkan dana taktis. Semua informan menyatakan bahwa hal ini adalah sesuatu yang salah, tetapi empat informan harus tetap melakukannya karena suatu keadaan yang memaksa mereka. Temuan ini sesuai dengan penelitian Setiawan (2013) yang menyatakan bahwa sistem untuk memperoleh dana taktis sebagai system driven (un) fraud merupakan tradisi turun temurun yang telah diketahui oleh semua anggota organisasi yang dilakukan secara berjamaah karena di dorong sistem yang "memaksa" dan bukan bentuk fraud sepenuhnya tetapi tidak dapat dibenarkan.

Alasan ketiga dalam penyiasatan laporan kegiatan yang dilakukan informan adalah ketakutan untuk dipindahtugaskan/dimutasi. Mutasi atau dipindahtugaskan menjadi ketakutan bagi aparatur karena aparatur merasa sudah nyaman bekerja di instansi ini dan dekat dengan keluarganya. Ungkapan ketakutan akan dipindahtugaskan/dimutasi ketika tidak mengikuti atasan diungkapkan oleh informan sebagai berikut:

"Gak bisa....kalau mau merubah, bisa di mutasi... kamu pilih mana papua apa maluku? Pindah langsung. Iya....disini aja kayak gitu....ngelawan dikit 
pindahin ke buleleng dah. Iya....selama yang di atas kayak gitu punya surat sakti, punya pulpen sakti, tinggal mutasi sudah. Enak-enak disini punya rumah dipindahin....” (M.J1-46)

"Emang mau di pindah kemana kamu...tinggal terima SK aja besok, susah kayaknya mbak mau nerapkan kayak gitu...” (M.H1-50)

Mutasi/dipindahtugaskan dapat dijadikan retaliasi (pembalasan) oleh pimpinan kepada bawahan yang tidak mengikuti perintahnya. Seperti yang diungkapkan Liyanarachchi \& Newdick (2009); Tsui \& Ferdinand (1996) bahwa atasan kemungkinan akan melakukan retaliasi seperti memindahtugaskan, mengurangi insentif, atau memecat akuntannya jika perintahnya tidak dipatuhi oleh bawahan. Hal inilah yang menjadi alasan informan masih tetap melakukan penyiasatan pelaporan yang tidak sesuai dengan riilnya. Temuan ini sesuai dengan penelitian Sofyani dan Pramita (2015) yang menyatakan bahwa retaliasi memiliki pengaruh yang lebih kuat daripada otoritas atasan untuk melakukan kecurangan.

\section{Model Pemahaman dan Realitas Workplace Spirituality dalam Perencanaan dan Pelaksanaan Anggaran}

Realitas workplace spirituality dalam perencanaan dan pelaksanaan anggaran yang tidak sejalan dengan pemahaman workplace spirituality perspektif informan, disebabkan masih adanya bentuk penyimpangan. Bentuk penyimpangan ini berupa niatan memaksimalkan anggaran untuk mendapatkan kelebihan dan kecurangan pelaporan pertanggungjawaban kegiatan anggaran yang berbeda dengan riilnya karena perilaku aparatur baik pimpinan maupun pelaksana masih mengabaikan nilai-nilai spiritual yang dimiliki dalam proses perencanaan dan pelaksanaan anggaran. Rahman (2012 dalam Mansyur, 2013) menyatakan bahwa maraknya korupsi disebabkan oleh satu diantaranya yaitu adanya pengabaian 
nilai-nilai agama dan norma-norma di masyarakat. Setiawan (2015) menyatakan "sisi gelap" pengelolaan keuangan daerah (dana taktis) disebabkan karena tidak termanifestasi iman Islam dalam tindakan nyata sehari-hari, dan masih maraknya nuansa sekularisme pada masyarakat beragama yang menjadikan simbol-simbol formalitas sebagai tolok ukur kesalehan, jubah dan kopyah menunjukkan identitas Islam yang lebih dihormati dibanding substansi ruh perbuatannya. Nilai-nilai agama belum terimplementasi dalam kehidupan sehari-hari, karena hanya dijadikan simbol, pengetahuan serta kepura-puraan saja (Windarto, 2016).

Realitas workplace spirituality dalam perencanaan dan pelaksanaan anggaran yang belum sesuai dengan pemahaman informan tentang workplace spirituality, membuat peneliti mengidentifikasi beberapa faktor yang dapat menjadi penghubung dalam implementasi workplace spirituality dalam perencanaan dan pelaksanaan anggaran pada objek penelitian. Faktor penghubung tersebut dapat menjadi penyebab terjadi realitas workplace spirituality yang menyimpang dan dapat juga menjadi penyelaras antara pemahaman dan realitas workplace spirituality dalam perencanaan dan pelaksanaan anggaran. Beberapa faktor ini, peneliti simpulkan ungkapan informan yang menyatakan bahwa penyebab terjadinya penyimpangan adalah atasan, tradisi turun temurun dan ketakutan dimutasi yang terjemahkan peneliti sebagai suprastruktur pimpinan, lingkungan kerja, dan personal value. Jika digambarkan dalam sebuah perumusan model, maka model pemahaman dan realitas workplace spirituality dalam perencanaan dan pelaksanaan anggaran dengan faktor penghubung dapat ditampilkan seperti pada Gambar 1 berikut: 


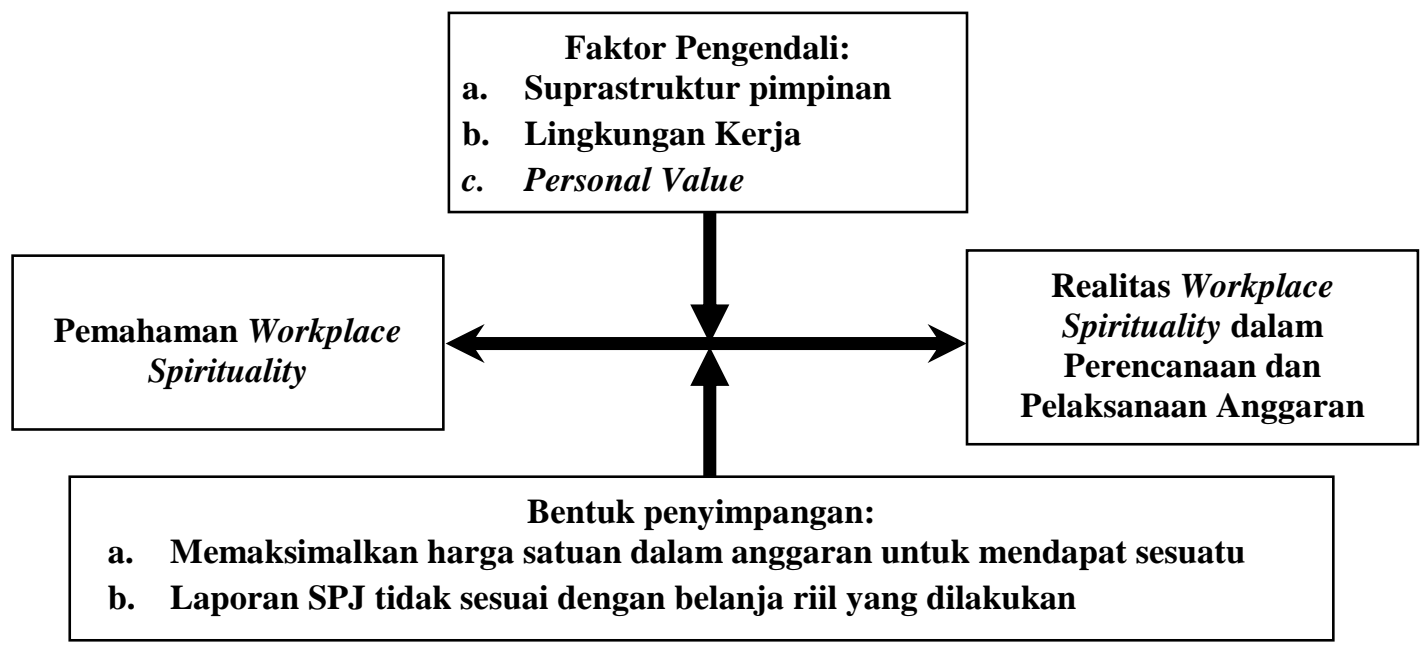

Gambar 1

Model Pemahaman Workplace Spirituality dan Realitas Penyimpangan dalam Perencanaan dan Pelaksanaan Anggaran

Sumber: Dikembangkan peneliti, 2017

Suprastruktur pimpinan sebagai faktor penghubung antara pemahaman dan realitas workplace spirituality dalam perencanaan dan pelaksanaan anggaran, karena pimpinan memiliki tanggung jawab untuk mengelola suprastruktur yang ada dalam organisasi. Selain itu, otoritas atasan atas bawahan memiliki peranan penting dalam menggerakkan bawahan untuk mengikuti perintahnya. Oleh karena itu, pimpinan menjadi faktor penggerak utama dalam mencapai keberhasilan tujuan instansi. Seperti yang dikatakan oleh Junaidi dan Halimah bahwa kecurangan laporan SPJ berawal dari atasan, jika atasan menetapkan kebijakan yang salah maka secara otomatis bawahan akan mengikutinya dengan karakter sistem yang telah menjadi rahasia umum.

Ungkapan kedua informan di atas dapat diartikan bahwa suprastruktur pimpinan memegang peranan penting dalam mengarahkan instansi pemerintah untuk merealisasikan workplace spirituality secara utuh dalam perencanaan dan 
pelaksanaan anggaran. Suprastruktur pimpinan yang paling tinggi harus mempertimbangkan nilai-nilai spiritualitas dalam penentuan kebijakannya, sehingga bawahan dapat merealisasikannya dalam sistem birokrasi pemerintahan. Kebijakan yang berdasarkan nilai-nilai spiritualitas di dalamnya akan menghasilkan perencanaan dan pelaksanaan anggaran yang sesuai dengan aturan dan ajaran agama. Fry (2003) menyatakan bahwa seorang pimpinan yang memiliki nilai-nilai spiritual, akan memiliki inner spirit yang dapat ditularkan kepada bawahannya. Tetapi jika pimpinan melalui otoritasnya memerintahkan bawahan untuk melakukan kecurangan, maka bawahan akan melakukan kecurangan tersebut dengan mempersepsikan tanggung jawab kecurangan berada di tangan atasannya (Murphy \& Mayhew, 2012; Sofyani dan Pramita, 2014; Bawa dan Yasa, 2016). Akhirnya, suprastruktur pimpinan akan mempengaruhi perilaku bawahan dalam perencanaan dan pelaksanaan anggaran.

Lingkungan kerja menjadi faktor penghubung kedua, karena suprastruktur pimpinan tidak sepenuhnya dapat merubah realitas dalam perencanaan dan pelaksanaan anggaran yang sudah menjadi tradisi turun temurun di dalam instansi, sehingga diperlukan perubahan pada lingkungan kerja instansi. Lingkungan kerja dianggap penting karena dapat mengarahkan seseorang untuk mencapai tujuan dan menciptakan suasana yang lebih baik di tempat kerja (Husein dan Hady, 2012). Menyetir kembali pendapat Yongki yang mengatakan bahwa "konsep pemikirannya masih orde baru, dimana dari dulu pembiarannya dibiarkan terus kan, sudah terbiasa jadinya, jadi budaya lama-lama, dan itu hal yang salah di anggap jadi benar aja... terlalu dibiarkan...”(M.Y1-38). Ungkapan Yongki 
mengandung arti bahwa lingkungan kerja instansi membiarkan sesuatu yang salah tetap terlaksana, tanpa adanya motivasi untuk melakukan suatu perbaikan sehingga diikuti oleh seluruh anggota instansi. Pembiaran ini tidak hanya disetujui oleh pimpinan instansi, tetapi juga oleh badan pemeriksa karena pemeriksaan yang dilakukan masih sebatas sisi administrasi yang sesuai dengan aturan dan belum menyentuh aspek prosesnya.

Kebiasaan turun temurun yang menjadi penyebab penyimpangan dapat dikatakan sebagai lingkungan kerja psikososial, karena kondisi ini telah diperlakukan dan diterima oleh semua anggota organisasi. Lingkungan kerja psikososial akan berdampak pada performa dan perilaku aparatur di tempat kerja (Rahajaan, dkk, 2016). Lingkungan kerja psikososial yang seperti ini perlu untuk diubah atau dihilangkan, dimana perubahan ini merupakan tugas semua anggota instansi yang dimulai dari pimpinannya, dan perlu saling mengingatkan untuk selalu berada di jalur yang benar dan baik. Perubahan lingkungan kerja psikososial yang mengarah kepada nilai-nilai spiritual yang diyakini informan dan tercermin dalam budaya organisasi instansi diharapkan dapat berdampak pada perilaku aparatur dalam perencanaan dan pelaksanaan anggaran yang tidak menyimpang dari aturan dan nilai-nilai spiritual. Perubahan lingkungan kerja psikososial yang mengarah kepada implementasi workplace spirituality akan membawa perilaku aparatur yang bersih dalam perencanaan dan pelaksanaan anggaran. Perencanaan dan pelaksanaan anggaran yang berlandaskan workplace spirituality akan membawa instansi pemerintah menjadi instansi spiritual. 
Setiap aparatur dalam instansi memiliki nilai-nilai personal yang dianutnya sebagai makhluk spiritual. Nilai-nilai personal (personal value) ini merupakan suatu keyakinan aparatur yang dapat mengarahkan perbuatan dan cara mereka dalam pengambilan keputusan (Rokeach, 1973 dalam Hari 2015). Jika nilai-nilai personal yang diakui informan seperti sikap pasrah, mengalah, bekerja sesuai dengan aturan, bekerja dengan kejujuran,bekerja dengan amanat, bekerja dengan baik, bekerja dengan ketekunan menjadi sebuah konsep workplace spirituality dalam perencanaan dan pelaksanaan anggaran dilaksanakan dengan baik, maka bentuk penyimpangan yang ada tidak akan terjadi. Selain itu, rasionalisasi ketakutan yang menjadi alasan informan untuk melakukan penyimpangan dapat dianggap sebagai sebuah tantangan untuk melakukan suatu kebaikan, maka penyimpangan ini mungkin tidak akan terjadi. Mengedepankan suatu aturan dan kejujuran adalah sesuatu yang baik, sehingga aturan dan prinsip kejujuran dapat menjadi alasan untuk menolak perintah atasan Jika nilai-nilai yang diyakini informan sebagai nilai spiritual diaplikasikan dengan baik, maka perilaku mereka dalam proses perencanaan dan pelaksanaan anggaran akan bernilai spiritual. Perencanaan dan pelaksanaan anggaran yang berlandaskan nilai-nilai spiritual akan menciptakan kedamaian, ketenteraman dan kebahagiaan bagi aparatur di tempat kerja. Nilai-nilai personal (personal value) aparatur yang baik akan mempengaruhi perilaku aparatur di tempat kerja, dimana value seseorang sangat mempengaruhi sikap dan perilakunya (Rokeach, 1973).

Penelitian ini sesuai dengan penelitian Ferreira (2013) dan Rachman, dkk (2014) yang menyatakan bahwa untuk menumbuhkan workplace spirituality 
kemungkinan dapat melalui faktor-faktor seperti lingkungan organisasi, individu dan kepemimpinan. Dimana lingkungan organisasi harus mendukung keseimbangan nilai spiritual dan nuasa kerja yang bermoral, individu harus memiliki keyakinan untuk bekerja sesuai dengan aturan, serta pimpinan yang diharapkan adalah pemimpin yang spiritual, memberikan keteladanan dan memahami anak buahnya.

\section{SIMPULAN DAN SARAN}

Penelitian ini mempunyai tujuan untuk mencari pemahaman aparatur tentang workplace spirituality dan implementasi serta realitas workplace spirituality dalam perencanaan dan pelaksanaan anggaran. Temuan penelitian menyatakan bahwa pemahaman aparatur tentang workplace spirituality dapat dilihat dari tiga sudut pandang yang berbeda yaitu pandangan instrinsik, pandangan agama dan pandangan eksistensialis. Walaupun pemahaman aparatur berbeda-beda, tetapi memiliki muara yang sama yaitu menilai pekerjaan sebagai tanggung jawab spiritual kepada Tuhan. Penelitian ini juga menemukan temuan baru dimana workplace spirituality merupakan suatu bentuk ucapan syukur kepada Tuhan dan ketekunan dalam bekerja untuk mencapai hasil yang maksimal.

Pemahaman workplace spirituality oleh aparatur telah berusaha diimplementasikan dalam perencanaan dan pelaksanaan anggaran melalui sikap sikap pasrah dan mengalah; mengawali bekerja dengan sebut nama Tuhan, berdoa, sesaji; bekerja sesuai aturan; bekerja dengan tujuan memberi kepada umat; saling membantu, saling menerima dan rasa kekeluargaan terhadap rekan kerja dalam satu organisasi. Namun, realitas workplace spirituality dalam 
perencanaan dan pelaksanaan anggaran tidak sepenuhnya menghadirkan nilai-nilai spiritualitas yang diyakini informan, karena proses perencanaan dan pelaksanaan anggaran masih memiliki indikasi penyimpangan seperti memaksimalkan anggaran sesuai aturan untuk mendapatkan kelebihan bagi kepentingan tertentu dan pelaporan pertanggungjawaban kegiatan yang tidak sesuai dengan riilnya untuk mendapatkan dana tambahan yang disebut dana taktis. Bentuk penyimpangan ini terjadi karena perilaku aparatur baik pimpinan maupun pelaksana masih mengabaikan nilai-nilai spiritual dalam proses perencanaan dan pelaksanaan anggarannya yang disebabkan oleh otoritas atasan, kebiasaan turun temurun dan ketakutan aparatur.

Realitas workplace spirituality dalam perencanaan dan pelaksanaan anggaran yang tidak sejalan dengan pemahaman aparatur, karena adanya bentuk penyimpangan memerlukan faktor penghubung yang akan membawa perubahan dalam implementasi workplace spirituality dalam perencanaan dan pelaksanaan anggaran yaitu supratruktur pimpinan, lingkungan kerja dan personal value. Ketiga faktor ini dapat menjadi penyelaras sekaligus penyebab terimplementasinya workplace spirituality sepenuhnya dalam perencanaan dan pelaksanaan anggaran untuk mewujudkan instansi spiritual.

Penelitian ini memberikan saran kepada Satker Kanwil Kemenag sebagai objek penelitian agar selalu terus berusaha untuk meningkatkan nilai-nilai spiritualitas dalam organisasi terutama pada perencanaan dan pelaksanaan anggaran untuk meminimalisir bentuk penyimpangan yang terjadi. Pembinaan nilai-nilai spiritualitas tidak hanya dilakukan kepada staf aparatur tetapi harus 
dimulai dari pucuk pimpinan sebagai pengampu kebijakan dalam anggaran melalui pelatihan pembinaan mental spiritual dengan pola pendidikan berkarakter. Peneliti selanjutnya dapat meneruskan penelitian yang sejenis terkait workplace spirituality dengan paradigma berbeda dan berfokus pada perilaku aparatur terhadap slack anggaran dengan melibatkan pejabat sebagai informan supaya dapat menemukan hasil yang lebih variatif seperti intensitas tanggungjawab. Model pemahaman dan realitas workplace spirituality terhadap penyimpangan dengan faktor kontijensi perlu diujikan kembali melalui penelitian kuantitatif.

\section{IMPLIKASI HASIL PENELITIAN}

Penelitian ini telah mengungkap pemahaman para pelaku perencana dan pelaksana anggaran mengenai pemahaman workplace spirituality dan realitasnya dalam perencanaan dan pelaksanaan anggaran. Hasil temuan penelitian ini diharapkan memiliki implikasi pada perubahan cara pandang aparatur instansi baik dari level pimpinan sampai staf agar dapat menerapkan semangat workplace spirituality dalam aktivitas perencanaan dan pelaksanaan anggaran sehingga menghasilkan perencanaan dan pelaksanaan anggaran yang sesuai dengan aturan dan tidak bertentangan dengan ajaran agama. Upaya perbaikan harus terus ditingkatkan walaupun memerlukan waktu yang cukup lama untuk merubah tradisi dan kebiasaan di instansi melalui pembinaan mental spiritual dengan pola pendidikan berkarakter untuk menumbuhkan nilai-nilai spiritualitas dalam diri setiap aparatur mulai dari level pimpinan sampai staf. Pimpinan instansi dapat menerapkan pola kepemimpinan berbasis spiritual yaitu memimpin dengan hati berdasarkan pada etika religius, mampu membentuk karakter, integritas dan 
keteladanan (Tobroni, 2012; Setiyati dan Santosa, 2017) untuk membawa instansi Kemenag menuju instansi spiritual.

Secara teoritis penelitian ini dapat berimplikasi pada potensi pengembangan pemahaman workplace spirituality dari berbagai sudut pandang, mengingat penelitian tentang workplace spirituality merupakan pengembangan baru dalam research. Hasil pengimplementasian workplace spirituality dalam perencanaan dan pelaksanaan anggaran seperti sikap pasrah dan mengalah, selalu mengawali dengan sebut nama Tuhan, berdoa, persembahyangan dengan sesaji, bekerja sesuai dengan aturan dan memberi untuk umat, sikap saling membantu, kekeluargaan dan saling menghargai dapat dipertimbangkan menjadi bentuk pengukuran dimensi masing-masing workplace spirituality selanjutnya. Hasil penelitian ini masih menitikberatkan pada pelaksanaan anggaran dengan informan penelitian adalah staf, sehingga model pemahaman dan realitas workplace spirituality hanya menghasilkan tiga faktor kontijensi yaitu suprastruktur pimpinan, lingkungan kerja dan personal value padahal masih ada kemungkinan faktor lain seperti intensitas tanggungjawab.

Penelitian ini memiliki keterbatasan pada waktu pengamatan yang hanya 2 bulan (Juli - Agustus 2017) dan informan penelitiannya adalah staf. Waktu pengamatan 2 bulan merupakan waktu yang sangat singkat untuk menggali lebih dalam informasi terkait pemahaman workplace spirituality dalam perencanaan dan pelaksanaan anggaran. Selain itu, wawancara kepada staf belum dapat mengungkapkan pemahaman workplace spirituality dari tingkat yang paling atas sebagai pengambil kebijakan. 


\section{REFERENSI}

Abdullah, S. dan Asmara, J. A. 2006. Perilaku oportunistik legislatif dalam penganggaran daerah: bukti empiris atas aplikasi agency theory di sektor publik. Prosiding Simposium Nasional Akuntansi IX. Padang, 23-26 Agustus 2008.

Agustian, Ari Ginanjar. 2007. Rahasia Sukses Membangun Kecerdasan Emosi dan Spiritual Berdasarkan 6 Rukun Iman dan 5 Rukun Islam. Cetakan Ke empat puluh. Jakarta: Arga.

Ahmad, Aminah \& Omar, Zaharah. 2016. Workplace spirituality among malaysian community service employees in the public sector. Asian Social Science, 12(9): 193-201.

Amalia, Filhaq dan Yunizar. 2007. Perilaku dan spiritualitas di tempat kerja. Jurnal Bisnis dan Manajemen, Fakultas Ekonomi, Universitas Padjajaran (diakses tanggal 24 Januari 2017)

Ashmos, D. P., \& Duchon, D. (2000). Spirituality at work: A conceptualization and measure. Journal of Management Inquiry, 9(2): 134-145.

Badan Pemeriksaan Keuangan (BPK). 2015. Ikhtisar Hasil Pemeriksaan Semester I Tahun 2016. Tersedia pada www.bpk.go.id, (diakses tanggal 12 Februari 2017)

Bastian, I. 2006a. Akuntansi Sektor Publik: Suatu Pengantar. Jakarta: Erlangga.

Bawa, Agus Artha dan Yasa, Gerianta Wirawan. 2016. Efek Moderasi Locus of Control pada Hubungan Otoritas Atasan dan Kecurangan Akuntansi. E-Jurnal Ekonomi dan Bisnis Universitas Udayana, 5(5): 1057-1086

Bungin, M. Burhan. 2009. Penelitian Kualitatif: Komunikasi, Ekonomi, Kebijakan Publik, dan Ilmu Sosial Lainnya. Jakarta: Kencana.

Chariri, Anis. 2009. Landasan Filsafat dan Metode Penelitian Kualitatif. Paper disajikan pada Workshop Metodelogi Penelitian Kuantitatif dan Kualitatif. Laboratorium Pengembangan Akuntansi (LPA), Fakultas Ekonomi Universitas Diponegoro, Semarang, 31 Juli - 1 Agustus 2009.

Creswell, J. W. 2007. Qualitative Inquiry and Research Design: Choosing Among Five Approaches. 2nd ed. United State of America: Sage Publications, Inc.

Dwirandra, A.A.Ngurah Bagus. 2011. Rekonstruksi metode penilaian aset dengan filosofi "Tri Hita Karana". Disertasi tidak dipublikasikan. Malang: Universitas Brawijaya. 
Fry. 2003. Toward a theory of spiritual leadership. The Leadership Quarterly, 14: 693-727.

Guillory, W. A. (2000). The living organizations: Spirituality in the workplace: A guide for adapting to chaotically changing workplace. Salt Lake City: Innovations International.

Gupta, Vinod Kumar and Singh, A.P. 2016. Conceptualization and Organizational Outcome Correlates of Spirituality at Work. Indian Journal of Community Psychology, 12(2): 391-403.

Hapsari, Septi, Titi Nurfitri, dan Eling Purwanto Jati. 2015. Analisis Pengaruh Human Relation Dukungan Organisasional dan Workplace Spirituality Terhadap Etos Kerja dan Pengaruhnya Terhadap Kinerja Karyawan (Studi Kasus pada Karyawan Bagian Keperawatan RS. Mitra Siaga Tegal). Performance, 21(1): 6680 .

Hari, Abdul Hadi. 2015. Peran Nilai-Nilai Personal (Personal Value) Terhadap Sikap Konsumen. Magistra, 92: 35-44.

Harlos, K. P. 2000. Toward a spiritual pedagogy: Meaning, practice, and applications in management education. Journal of Management Education, 24: 612-630.

Haryokusumo, Diaz. 2015. The Effect of Workplace Spirituality Dimensions on Organizational Commitment with Perceived Organizational Support as A Moderating Variable. Jurnal Dinamika Manajemen (JDM), 6(2): 187-202.

Hasiara, L. O. 2012. Sikap dan Perilaku Aparatur sebagai Mediator dalam Penyusunan KUA dan PPAS. Jurnal Akuntansi Multiparadigma, 2(3): 510-530.

Ikhsan, Budi Riharjo, Isnadi. 2011. Perilaku Oportunistik Pejabat Eksekutif Dalam Penyusunan APBD (Bukti Empiris atas Penggunaan Penerimaan Sumber Daya Alam). Jurnal Ekuitas, 14(3): 388-411.

James, M. S., Miles, A. K., \& Mullins, T. 2011. The interactive effects of spirituality and trait cynicism on citizenship and counterproductive work behaviors. Journal of Management, Spirituality \& Religion, 8(2): 165-182

Javanmard, H. 2012. The impact of spirituality on work performance, Indian Journal of Science and Technology, 5(1).

Juono, Umar. 2009. Respon Opini Disclaimer Pada Laporan BPK Terhadap Audit LKPP. Jakarta: Suara Karya Online. 
Kamayanti, Ari. 2016. Metodelogi Penelitian Kualitatif Akuntansi: Pengantar Religiositas Keilmuan. Jakarta: Yayasan Rumah Peneleh.

Krishnakumar, S. \& Neck. C. P. (2002). The "what", "why" and "how" of spirituality in the workplace. Journal of Managerial Psychology, 17(3): 153-164.

Kumari, N. 2013. Business ethics and corporate social responsibility: A holistic approach. VSRD Internasioal Journal of Business and Management Research, 3(3): 97-102.

Kuswarno, E. 2009. Fenomenologi: Konsepsi, Pedoman dan Contoh Penelitian. Bandung: Widya Padjajaran.

Liyanarachchi, Gregory and Newdick, Chris. 2009. The Impact of Moral Reasoning and Retaliation on Whistle-Blowing: New Zealand Evidence. Journal of Business Ethics, 89: 37-57

MalikehBeheshtifar and Zare, Elham. 2013. Effect of Spirituality in Workplace on Job Performance. Interdisciplinary Journal Of Contempory Research In Business, 5(2): 248-254.

Mansyur, Ahmad Yasser. 2013. Personal Prophetic Leadership Sebagai Model Pendidikan Karakter Intrinsik Atasi Korupsi. Jurnal Pendidikan Karakter, 1(3): $15-26$

Mardiasmo. 2009. Akuntansi Sektor Publik. Andi: Yogyakarta

Mulia, Annisa Sekar. 2012. Mengungkap Pemahaman Tentang Akuntansi Dari Kecerdasan Emosional, Spiritual dan Sosial Mahasiswa. Jurnal Akuntansi Multiparadigma, 3(3): 334-501.

Mulyono, Wastu Adi. 2011. Penerapan Spiritualitas di Tempat Kerja di RS. F dan Hubungannya dengan Kepuasan Kerja Perawat. Jurnal Keperawatan Soedirman, 6(2): 96-102.

Moleong, L. 2014. Metodologi Penelitian Kualitatif. Bandung: PT. Remaja Rosdakarya.

Murphy, P. R \& Mayhew, B. W. 2012. The Impact of Authority on Reporting Behaviour. SSRN Electronic Journal. (Electronic copy available at: http://ssrn.com/abstract=2026449)

Nurtjahjanti, Harlina., 2010. Spiritualitas Kerja Sebagai Ekspresi Keinginan Diri Karyawan Untuk Mencari Makna Dan Tujuan Hidup Dalam Organisasi. Jurnal Psikologi Undip, 7(1). 
Pawar, Badrinarayan Shankar. 2008. Individual Spirituality, Workplace Spirituality And Work Attitudes An Empirical Test of Direct And Interaction Effects. Leadership \& Organization Development Journal, 30 (8): 759-777.

Pradiansyah, Arvan. 2007. Spiritualitas Dalam Bisnis: Lahirnya Generasi Ketiga. SWA sembada, No 05/XXIII/1-14 Maret 2007: 63-64.

Prihono, I K Budiartha, I B Putra Astika. 2016. Pengaruh Motivasi, Budaya Organisasi, dan Spiritualitas pada Kinerja Pegawai Kantor Pelayanan Perbendaharaan Negara di Provinsi Bali. E-Jurnal Ekonomi dan Bisnis Universitas Udayana, 5(7): 2063-2090.

Poole, E. 2009. Organizational spirituality: A literature review. Journal of Business Ethics, 84(10): 577-588.

Rachman, Sutan WHS, Soesilo Zauhar, dan Choirul Saleh. 2014. Workplace Spirituality Tenaga Kependidikan Universitas Brawijaya (Studi Pada Fakultas Ilmu Pengetahuan Alam dan Matematika Serta Fakultas Ilmu Sosial dan Ilmu Politik. Wacana, 17(4): 171-182.

Rahajaan, Thoman E.V, Bambang Swasto, Kusdi Rahardjo. 2016. Pengaruh Karakteristik Pekerjaan Terhadap Lingkungan Kerja, Stress Kerja, Kepuasan Kerja dan Organizational Citizen Behavior. Jurnal Profil, 6 (2): 104-116.

Rahayu, Sri, Unti Ludigdo, dan Didied Affandy. 2007. Studi Fenomenologi Terhadap Penyusunan Anggaran Daerah Bukti Empiris Dari Satuan Kerja Perangkat Daerah di Provinsi Jambi. Simposium Nasional Akuntansi X, Makasar, 26-28 Juli 2009.

Razak, A., U. Ludigdo, EG. Sukoharsono dan A. Thoyib. 2011. Perilaku Kuasa Eksekutif dan Legislatif dalam Proses Penyusunan Anggaran Pemerintah Daerah: Perspektif Interaksionisme Simbolik. Jurnal Akuntansi Multiparadigma, 2(3): 492-509.

Saladien. 2006. Rancangan Penelitian Kualitatif. Modul Metodologi Penelitian Kualitatif, Disampaikan pada Pelatihan Metodologi Penelitian Kualitatif Program Studi Ilmu Ekonomi, Fakultas Ekonomi, Universitas Brawijaya, 6-7 Desember 2006.

Setiawan, Achdiar Redy, Irianto Gugus, dan Achsin, M. 2013. System-Driven (Un) Fraud: Tafsir Aparatur Terhadap "Sisi Gelap" Pengelolaan Keuangan Daerah. Jurnal Akuntansi Multiparadigma, 4(1): 1-16

Setiawan, A. R dan Kamayanti, Ari. 2012. Mendobrak Reproduksi Dominasi Maskulinitas Dalam Pendidikan Akuntansi: Internalisasi Pancasila Dalam Pembelajaran Accounting Fraud. Prosidig Konferensi Nasional Pendidikan 
Akuntansi Indonesia, Jurusan Akuntansi FEB Universitas Brawijaya \& IAI KAPd.

Setiawan, Achdiar Redy. 2016. Al Halalu Bayn Wal Haroomu Bayn: Tafsir Agama(wan) atas Multitafsir "Sisi Gelap" Pengelolaan Keuangan Daerah. Jurnal Akuntansi Multiparadigma, 7(1): 17-35

Setiyati, Ritta dan Santoso, Lestanto Pudji. 2017. Kepemimpinan Berbasis Spiritual. Forum Ilmiah, 14(1): 94-100

Simamora, H. 2000. Manajemen Sumber Daya Manusia, Edisi Kedua. Yogyakarta: STIE YKPN.

Smith, J. A. and Rayment, J .J. 2007. The global SMP fitness framework: A guide for leaders exploring the relevance of spirituality in the workplace. Management Decision, 45(2): 217-234

Smith, Jonathan A, Flowers, Paul, and Larkin, Michael 2009. Interpretative phenomenological analysis: Theory, method and research. Los Angeles, London, New Delhi, Singapore, Washington: Sage.

Sopanah. 2012. Ceremonial Budgeting dalam Perencanaan dan Penganggaran Daerah: Sebuah Keindahan yang Meneipu. Prosiding Simposium Nasional Akuntansi XV, Banjarmasin, 20-23 September.

Sofyani, H dan Y.D. Pramita. 2014. Otoritas Atasan, Retaliasi dan Locus of Control sebagai Faktor-Faktor yang Memengaruhi Perilaku Manipulasi Laporan Realisasi Anggaran. Jurnal Reviu Akuntansi dan Keuangan, 3(2): 415-506.

Sprung, J.M., Sliter, M. T dan Jex, S.M. 2012. Spirituality as a moderator of the relationship between workplace aggression and employee outcomes. Personality and Individual Differencess, 53: 930-934.

Sufya, Dina Haya. 2015. Pengaruh Modal Psikologis, Budaya Organisasi dan Spiritualitas di Tempat Kerja Terhadap Organizational Citizenship Behavior. Tesis tidak dipublikasikan. Jakarta: Universitas Islam Negeri Syarif Hidayatullah.

Supeno, Hadi. 2009. Korupsi Kepala Daerah, APBD Sasaran Penyelewengan. Jakarta. http://www.beritabaru.com.

Stalebrink, O. J dan J. F. Sacco. 2007. Rationalization Of Financial Statement Fraud In Government: An Austrian Perspective, Critical Perspectives on Accounting, 18: 489-507.

Tobroni. 2005. Perilaku Kepemimpinan Spiritual Dalam Pengembangan Organisasi Pemdidikan dan Pembelajaran, Kasus Lima Pemimpin Pendidikan di 
Kota Ngalam. Disertasi tidak dipublikasikan. Yogyakarta: Universitas Islam Negeri Sunan Kalijaga.

Tsui, Judy S L. and Ferdinand A Gul. 1996. Auditors' Behaviour In An Audit Conflict Situation: A Research Note On The Role Of Locus Of Control And Athical Reasoning. Accounting, Organizations and Society, 21(1): 41-51.

Tuasikal, Askam. 2013. Fenomenologis Perencanaan dan Penganggaran Pemerintah Daerah. Jurnal Akuntansi Universitas Jember, hal: 78-91.

Transparency International (TI). 2017. Tersedia pada www.ti.or.id (diakses tanggal 12 Februari 2017).

Weitz, E., Vardi, Y., \& Setter, O. 2012. Spirituality and organizational misbehavior. Journal of Management, Spirituality \& Religion, 9(3): 255-281.

Windarto, Titus Eko. 2016. Pelaksanaan Anggaran Dalam Perspektif Workplace Spirituality. Tesis tidak dipublikasikan. Surabaya: Universitas Airlangga.

Yogatama, Leo Agung Manggala dan Widyarini Nilam. 2015. Kajian Spiritualitas di Tempat Kerja pada Konteks Organisasi Bisnis. Jurnal Psikologi, 42 (1): 1-14.

Zamor, J. C. G. 2003. Workplace Spirituality and Organizational Performance. Public Admnistration Review, 63(3). 